\title{
Effect of dietary fatty acid supplements, varying in fatty acid composition, on milk fat secretion in dairy cattle fed diets supplemented to less than $3 \%$ total fatty acids
}

\author{
C. M. Stoffel, P. M. Crump, and L. E. Armentano ${ }^{1}$ \\ Department of Dairy Science, University of Wisconsin, Madison 53706
}

\begin{abstract}
Dietary fatty acids can affect both milk fat yield and fatty acid (FA) composition. This relationship is well established when the dietary level of FA exceeds $3 \%$ of diet dry matter (DM). We could find no reports directly examining the effects of dietary FA profile on milk fat at levels below 3\%. Twenty-four primiparous and 36 multiparous lactating cows were paired by production (1 high with 1 low, within parity) to form 30 experimental units. Pairs were fed 6 diets in five $6 \times$ 6 balanced Latin squares with 21-d periods, and data were collected during the last $5 \mathrm{~d}$ of each period. Two control diets were fed: a corn control diet (CC; $29 \%$ corn silage, $16 \%$ alfalfa silage, $19 \%$ corn grain, and $8 \%$ distillers grain on a DM basis) containing $1.8 \% \mathrm{FA}$; and a low-oil control diet (LOC; $9 \%$ corn silage, $35 \%$ alfalfa silage, $20 \%$ food-grade corn starch, and $8 \%$ corn gluten feed on a DM basis) containing $1.2 \%$ FA. A portion of the food-grade corn starch in LOC was replaced with 4 different FA supplements to create the 4 treatment diets. Treatments were 1.7\% (DM basis) of a 50:50 blend of corn oil and high-linoleic safflower oil (LO), $1.7 \%$ high-oleic sunflower oil (OO), $1.7 \%$ palm oil (PO), or $1.8 \%$ calcium salts of palm fatty acids (PFA). The resultant diets were thus enriched in linoleic (LO), oleic $(\mathrm{OO})$, or palmitic acid (PO and PFA). Dietary treatments did not affect dry matter intake. Addition of any of the fat sources to LOC resulted in increased milk yield, but milk fat yields and milk FA composition were variable for the different treatments. The LO treatment resulted in lower milk fat yield, fat concentration, and C16:0 yield but increased both trans-10 C18:1 and trans-10, cis-12 C18:2 yields compared with the other added FA treatments. Diets PO and PFA resulted in increased milk C16:0 yield and decreased total milk C18 yield compared with OO. Regression analysis revealed a negative coefficient for dietary linoleic acid content over basal (LOC) for both milk short-chain FA yield
\end{abstract}

Received May 5, 2014.

Accepted July 16, 2014.

${ }^{1}$ Corresponding author: learment@wisc.edu and C16:0 yield. Dietary linoleic acid content also had a positive coefficient for milk trans-10 C18:1 and trans10,cis-12 conjugated linoleic acid yield. These results demonstrate that even when total dietary FA are below $3 \%$, free oils rich in linoleic acid can reduce milk fat yield by reducing secretion of milk FA with fewer than 18 carbons. Fatty acid composition of fat supplements is important even at this low level of total dietary fat. Key words: linoleic, oleic, palmitic, milk fat depression

\section{INTRODUCTION}

Fat fed to dairy cows can come from fat endogenously present in the feed ingredients or added in supplements. Previous experiments in which free vegetable oils were added as supplements found that the variation in the FA composition of added oils can affect milk fat yield (Grummer, 1991). Vegetable oils, such as those found in common feeds and some fat supplements, vary in contents of oleic, linoleic, and palmitic acids. The unsaturated FA found in these vegetable oils are not inert in the rumen, but rather are subject to biohydrogenation. Complete biohydrogenation converts all ingested unsaturated FA into saturated FA (Harfoot and Hazlewood, 1997). Accumulation of bioactive intermediates from incomplete biohydrogenation contributes to reduced milk fat secretion, a condition known as milk fat depression (MFD; Chouinard et al., 1999b; Perfield et al., 2007; Shingfield et al., 2009). One bioactive FA that has been identified as a significant cause of dietary induced MFD is trans-10,cis-12 CLA, a biohydrogenation product of linoleic acid (cis-9,cis-12 C18:2; Baumgard et al., 2000). As dietary starch is increased at the expense of fiber, rumen bacterial biohydrogenation of unsaturated FA can shift toward the formation of this and other bioactive FA (Griinari et al., 1998; Loor et al., 2004). In these diets, or when pure milk fat depressing FA are infused (Baumgard et al., 2000, 2001), MFD is a result of increased bioactive FA with a constant supply of dietary FA. Almost all milk short-chain $(<\mathrm{C} 16) \mathrm{FA}$ are synthesized by the mammary gland along with roughly half of the palmitic acid (C16:0). The other half of the 
C16:0 and the majority of the 18-carbon $(\mathrm{C} 18)$ and longer FA are of dietary origin (Bauman and Davis, 1974). For the purpose of this paper, the abbreviation $<\mathrm{C} 16$ will include all milk FA shorter than 16 carbons, C16:0 will denote milk $\mathrm{C} 16: 0$, and $\mathrm{C} 18$ will denote all 18-carbon FA, regardless of saturation. The exact proportion of C16:0 from diet or mammary synthesis can vary and is partly dependent on the palmitic acid content of the diet (Palmquist, 2006). Trans-10 C18:1, a biohydrogenation product of both linoleic and oleic acid, has also been linked to MFD (Shingfield et al., 2009). Bioactive FA decrease mammary gland FA synthesis, which reduces milk $<\mathrm{C} 16$ and $\mathrm{C} 16: 0 \mathrm{FA}$ yields; however, bioactive FA can also inhibit incorporation of blood C16:0 and C18 FA into milk fat (Baumgard et al., 2001). Supplemental unsaturated FA, therefore, can affect milk fat yield in 2 opposing ways: they supply additional substrate for bioactive FA formation and they supply more preformed FA for direct incorporation into milk fat. Whether a cow exhibits MFD in response to added dietary fat depends on the balance between depression of milk fat yield by bioactive FA and increased milk C16:0 and C18 FA by provision of dietary FA.

Figure 1 reports yield of milk $<\mathrm{C} 16$ and $\mathrm{C} 18 \mathrm{FA}$ for cows fed a fat supplement minus the milk $<\mathrm{C} 16$ and C18 FA yield achieved with a low-fat control diet from previous studies (open symbols). All diets in which the main supplementary FA was either C18:1 or C18:2 resulted in decreased milk $<\mathrm{C} 16 \mathrm{FA}$ yield, with the most severe decreases in $<\mathrm{C} 16 \mathrm{FA}$ being associated with supplemented C18:2. These diets also increased milk C18 yield. In contrast, for supplements in which the primary FA were a mixture of $\mathrm{C} 16: 0$ and $\mathrm{C} 18: 1$, the magnitude of decreased milk $<\mathrm{C} 16$ and increased $\mathrm{C} 18$ FA yields were both $80 \mathrm{~g} / \mathrm{d}$ or less. For supplements that contained almost completely $\mathrm{C} 16: 0$, the average milk FA yield response was negligible for both $<$ C16 and C18 FA. Although not shown in Figure 1, the response for milk C16:0 relative to the control averaged $-92.2,-72.0,32.4$, and $182.9 \mathrm{~g} / \mathrm{d}$ for primarily C18:2, C18:1, mixed C16:0 plus C18:1, or pure C16:0 diets, respectively. Although the studies in Figure 1 differed in their primary FA, other FA also varied among supplements.

It is well documented that diets supplemented with vegetable oils can cause MFD when fat content of the supplemented diets ranged from 3.6\% (DePeters et al., 2001) to $8.0 \%$ (Chilliard et al., 2009) of diet DM. However, we could find no research exploring the effects of feeding different dietary FA when the final dietary FA concentration remains below $3 \%$. Endogenous feed FA can contribute up to $3 \%$ of diet DM and might contribute to MFD. Additionally, the effects of trans-10, cis-12 CLA on milk fat yield and concentration appear to be curvilinear, with greater MFD per unit of increased trans-10,cis-12 CLA at lower infusion doses than at higher doses (Peterson et al., 2002).

The objective of this study was to examine the effect of oils rich in linoleic, oleic, or palmitic acid on milk fat secretion when supplemented at levels to achieve total dietary FA levels below 3\% of DM. We hypothesized that (1) dietary linoleic acid would reduce the secretion of milk $\mathrm{C} 16: 0$ and $<\mathrm{C} 16 \mathrm{FA}$, which would offset any positive effects of increased dietary $\mathrm{C} 18$ on milk C18 yield; (2) dietary oleic acid would result in less depression of C16:0 and $<$ C16 FA yields compared with linoleic acid, while still providing preformed $\mathrm{C} 18$ to be incorporated into milk fat; and (3) dietary palmitic acid would not depress milk $\mathrm{C} 16: 0$ or $<\mathrm{C} 16$ yield and would provide a source of preformed C16:0 for inclusion into milk. Therefore, we predicted the lowest fat yield with the linoleic-rich fat supplement and the greatest fat yield with fat supplements consisting of palmitic plus oleic, with an intermediate milk fat yield for the oleic-rich oil supplement. Our study did not address the effect of endogenous feed FA, which, by way of being

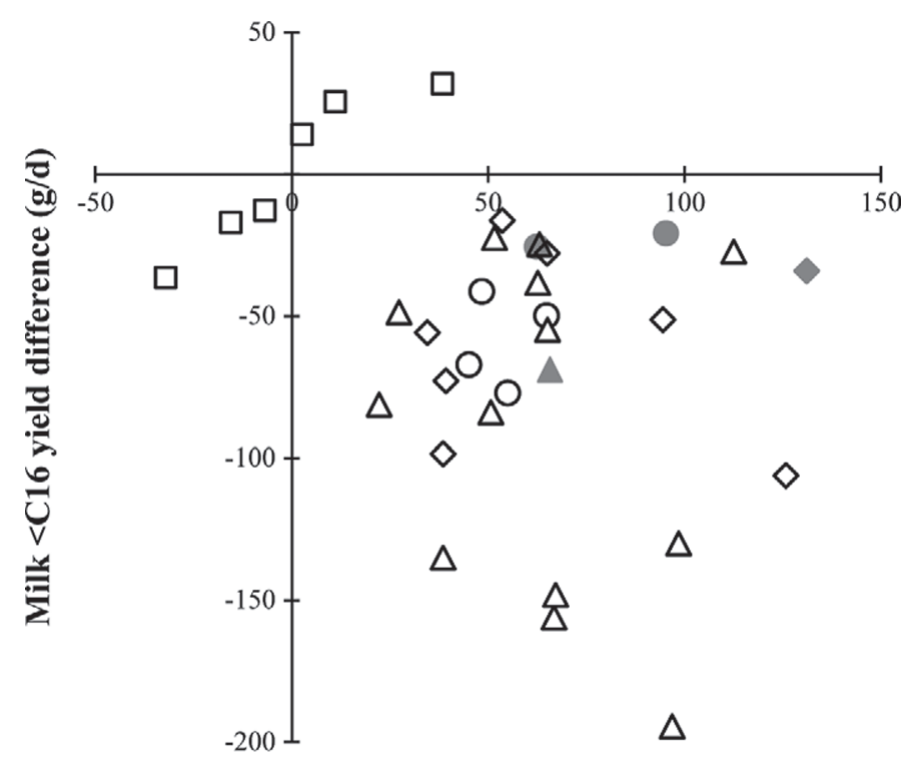

Milk total C18 yield difference (g/d)

Figure 1. Change in milk yield of $\mathrm{C} 18$ versus change in milk $<\mathrm{C} 16: 0$ yield in response to adding oils consisting primarily of C16:0 (squares), C16:0 + C18:1 (circles), C18:1 (diamonds), and C18:2 (triangles). Observations are yield of the indicated FA in milk for the oil supplemented minus the yield for a low-fat control diet. Data from the present study are presented in solid gray points. Data sources: Elliott et al. (1996); Kalscheur et al. (1997); Jenkins (1998); Fearon et al. (2004); Leonardi et al. (2005, 2012); Bell et al. (2006); Mosley et al. (2007); Bu et al. (2007); AlZahal et al. (2008); Warntjes et al. (2008); Huang et al. (2008); Abdelqader et al. (2009); Rego et al. (2009); Ye et al. (2009); He and Armentano (2011); Lock et al. (2013); Piantoni et al. (2013). 
incorporated in a feed particle rather than as free oil, may be protected physically from biohydrogenation. Instead, we examined the effect of FA external to the basal feed ingredients but at added concentrations similar to what could be supplied endogenously in common dairy cattle diets.

\section{MATERIALS AND METHODS}

\section{Description of the Experiment}

All animal use procedures were approved by the Animal Care and Use Committee for the College of Agricultural and Life Sciences at the University of Wisconsin-Madison. Twenty-four primiparous (117 \pm 19 DIM at the beginning of the covariate period, mean $\pm \mathrm{SD})$ and 36 multiparous $(116 \pm 21 \mathrm{DIM}$ at the beginning of the covariate period, mean $\pm \mathrm{SD}$ ) lactating dairy cows were housed in a freestall barn equipped with roughage intake control (RIC) system gates (Insentec BV, Marknesse, the Netherlands), which recorded individual cow feed intake continuously. Cows were blocked within parity into a high-producing group and a low-producing group based on predicted 305-d milk (DairyComp 305, Valley Agricultural Software, Tulare, CA). Within parity group, 1 high-producing cow was paired with 1 low-producing cow, and the pair was assigned to a single RIC gate for the entirety of the trial, resulting in 12 primiparous pairs and 18 multiparous pairs each assigned to 1 of 30 gates. Gates were assigned randomly, within parity, to one of five $6 \times 6$ Latin squares; thus, gate was the experimental unit. Each period lasted $21 \mathrm{~d}$, with $16 \mathrm{~d}$ for adaptation followed by $5 \mathrm{~d}$ of sample collection. Covariate data were also collected for $12 \mathrm{~d}$ before initiation of the first trial period. Cows were fed a TMR with feed delivered 3 times daily at 0400,1300 , and $1800 \mathrm{~h}$, and were allowed free access to water. The TMR was mixed once daily before the midday feeding and stored for delivery again in the evening and the following morning. Cows were fed ad libitum for $10 \%$ refusals. Refusals were removed daily before the midday feeding. Dry matter was measured on the forages once weekly, and as fed ingredient proportions were modified accordingly to maintain near constant proportions of feeds on a DM basis. Diets were formulated to meet the requirements of NRC (2001) for cows 100 DIM, producing $45 \mathrm{~kg}$ of milk daily, with $3.5 \%$ milk fat, $3.0 \%$ milk protein, and a target DMI of $25 \mathrm{~kg} / \mathrm{d}$.

Two control diets consisted of a corn-based control (CC) with $28.8 \%$ corn silage, $15.8 \%$ alfalfa silage, and $55.4 \%$ concentrate mix on a DM basis, and a low-oil control (LOC) with $9.4 \%$ corn silage, $34.9 \%$ alfalfa silage, and $55.7 \%$ concentrate mix on a DM basis (Table
1). The LOC diet was formulated to have similar NDF and $\mathrm{CP}$ to $\mathrm{CC}$ while having a lower FA content. The LOC and CC diets utilized feed-grade corn starch or ground corn grain as the primary starch source, respectively. Fat-supplemented dietary treatments were formulated by replacing part of the feed-grade corn starch in the LOC diet with different fat sources to make 4 treatments equal in total FA according to the Cornell-Penn-Miner implementation of the Cornell Net Carbohydrate and Protein System model (CPM Dairy; University of Pennsylvania, Kennett Square, PA; Cornell University, Ithaca, NY; and William H. Miner Agricultural Research Institute, Chazy, NY). Treatment diets were 1.7\% (DM basis) of a 50:50 blend of corn oil and high-linoleic safflower oil (LO; Sysco Baraboo LLC, Baraboo, WI; Alnor Oil Co., Valley Stream, NY), 1.7\% high-oleic sunflower oil (OO; Columbus Foods, Des Plaines, IL), $1.7 \%$ palm oil (PO; Columbus Foods), or $1.8 \%$ calcium salts of palm FA (PFA; Megalac; Church and Dwight Co. Inc., Princeton, NJ).

Individual concentrate mixes containing all concentrates and fat supplements were prepared for CC and PFA. A common concentrate mix was used for LOC, LO, OO, and PO. This common mix was then supplemented with either 1.7\% DM of feed-grade corn starch (LOC) or the respective oil (LO, OO, PO) when mixing the TMR. Oils were stored under nitrogen to reduce oxidation. The CC diet was fed to all cows during the covariate period. Treatment sequences were different for all squares but all squares were balanced for 1-period carryover effects. All animals received bST once every $14 \mathrm{~d}$ according to the manufacturer's instructions (Posilac; Elanco Animal Health, Greenfield, IN). Cows were milked twice daily at 0330 and $1530 \mathrm{~h}$.

During the trial, 4 cows were removed from the study due to health reasons. One cow was removed during the first period due to pneumonia; 2 were removed in the third period, 1 for reduced feed intake and 1 for lameness. The last cow was removed in the fourth period with a left displaced abomasum. These 4 cows were not used in the statistical analysis.

\section{Stealing}

Two additional cows were physically removed from the study pen due to their habitual consumption of feed from gates other than their own by forcibly displacing the cow assigned to the gate $(1 \mathrm{cow}$ in period 1 and 1 cow in period 2). In this situation, not only did the offending cow eat a diet that was not her own, but that amount of intake was incorrectly attributed to the displaced cow. Data collected from these cows before their removal from the pen were not used in the statistical analysis. 
Table 1. Ingredient and chemical composition of experimental diets

\begin{tabular}{|c|c|c|c|c|c|c|}
\hline \multirow[b]{2}{*}{ Item } & \multicolumn{6}{|c|}{ Treatment $^{1}$} \\
\hline & $\mathrm{CC}$ & LOC & $\mathrm{LO}$ & $\mathrm{OO}$ & $\mathrm{PO}$ & PFA \\
\hline \multicolumn{7}{|l|}{ Ingredient ( $\%$ of DM) } \\
\hline Corn silage & 28.8 & 9.4 & 9.4 & 9.4 & 9.4 & 9.4 \\
\hline Alfalfa silage & 15.8 & 34.9 & 35.0 & 34.9 & 34.9 & 35.0 \\
\hline Corn grain & 19.4 & - & - & - & - & - \\
\hline Dry ground distillers grain & 8.2 & - & - & - & - & - \\
\hline Corn starch, food grade ${ }^{2}$ & - & 20.1 & 18.3 & 18.3 & 18.3 & 18.6 \\
\hline Soybean meal, $48 \%$ CP & 10.2 & 10.1 & 10.1 & 10.1 & 10.1 & 10.1 \\
\hline Soy hulls & 7.2 & 12.2 & 12.2 & 12.2 & 12.2 & 12.2 \\
\hline Corn gluten feed, dried & 4.1 & 7.9 & 7.9 & 7.9 & 7.9 & 7.9 \\
\hline Corn and safflower oil ${ }^{3}$ blend & - & - & 1.7 & - & - & - \\
\hline High-oleic sunflower oil & - & - & - & 1.7 & - & - \\
\hline Palm oil & - & - & - & - & 1.7 & - \\
\hline Ca salts of palm FA & - & - & - & - & - & 1.8 \\
\hline Corn gluten meal & 1.0 & 1.0 & 1.0 & 1.0 & 1.0 & 1.0 \\
\hline Blood meal & 1.0 & 1.0 & 1.0 & 1.0 & 1.0 & 1.0 \\
\hline Mineral $\operatorname{mix}^{4}$ & 4.4 & 3.4 & 3.4 & 3.4 & 3.4 & 3.0 \\
\hline \multicolumn{7}{|l|}{ Chemical composition } \\
\hline DM (\%) & 54.8 & 58.7 & 58.8 & 58.8 & 58.8 & 58.8 \\
\hline $\mathrm{CP}(\%)$ & 18.5 & 19.2 & 19.2 & 19.2 & 19.2 & 18.8 \\
\hline NDF $(\%)$ & 28.2 & 27.9 & 27.9 & 27.9 & 27.9 & 28.4 \\
\hline $\mathrm{NFC}^{5}(\%)$ & 41.2 & 41.6 & 39.8 & 39.8 & 39.8 & 41.8 \\
\hline Starch $(\%)$ & 23.9 & 19.4 & 18.1 & 18.1 & 18.1 & 20.0 \\
\hline FA (\%) & 1.8 & 1.2 & 2.8 & 2.9 & 2.8 & 2.4 \\
\hline $\mathrm{NE}_{\mathrm{L}}^{6}(\mathrm{Mcal} / \mathrm{kg})$ & 1.68 & 1.64 & 1.70 & 1.70 & 1.70 & 1.62 \\
\hline Ash (\%) & 9.0 & 9.31 & 9.3 & 9.3 & 9.3 & 8.8 \\
\hline $\operatorname{ADF}(\%)$ & 17.8 & 19.2 & 19.2 & 19.2 & 19.2 & 18.8 \\
\hline $\mathrm{Ca}(\%)$ & 1.0 & 1.2 & 1.2 & 1.2 & 1.2 & 1.1 \\
\hline $\mathrm{P}(\%)$ & 0.5 & 0.5 & 0.5 & 0.5 & 0.5 & 0.5 \\
\hline K (\%) & 1.6 & 1.6 & 1.6 & 1.6 & 1.6 & 1.6 \\
\hline $\operatorname{Mg}(\%)$ & 0.5 & 0.4 & 0.4 & 0.4 & 0.4 & 0.4 \\
\hline \multicolumn{7}{|c|}{$\begin{array}{l}{ }^{1} \mathrm{CC}=\text { corn control, } \mathrm{LOC}=\text { low-oil control, } \mathrm{LO}=\text { corn and high-linoleic safflower oil, } \mathrm{OO}=\text { high-oleic sun } \\
\text { flower oil, } \mathrm{PO}=\text { palm oil, } \mathrm{PFA}=\text { calcium salt of palm FA. }\end{array}$} \\
\hline \multirow{2}{*}{\multicolumn{7}{|c|}{$\begin{array}{l}{ }^{2} \text { Food-grade corn starch was analyzed as } 73.6 \% \text { starch and } 99.5 \% \text { NFC. } \\
{ }^{3} \text { High linoleic safflower oil. }\end{array}$}} \\
\hline & & & & & & \\
\hline \multicolumn{7}{|c|}{$\begin{array}{l}{ }^{4} \text { Contained trace mineral salt, calcium carbonate, magnesium oxide, and sodium phosphate; potassium carbor } \\
\text { ate was also included in diet CC mineral mix. }\end{array}$} \\
\hline \multicolumn{7}{|c|}{${ }^{5}$ Calculated as $100-(\% \mathrm{NDF}+\% \mathrm{CP}+\%$ Fat + ash $)$} \\
\hline
\end{tabular}

Cows were also able to consume feed from 1 of the other 29 gates to which they were not assigned by reaching over the top of the closed gate barrier. In this case, the feed consumption was correctly recorded and correctly attributed to the offending cow; however, the cow did not solely consume her assigned diet. Data for any cow that consumed more than $5 \%$ of her intake from a nonassigned diet during the data collection phase of the period was removed from that period's data before statistical analysis. Any cow without at least 3 consecutive periods of data was also completely removed from the data set before analysis. Because of these constraints, an additional 84 cow-period cells were removed from the data. This resulted in the statistical analysis utilizing 246 of out of 360 possible cow-period cells and 42 out of 60 possible cows. Despite this loss of animals, only 1 entire experimental unit (gate) was lost from the data set for all 6 periods.

\section{Data Collection and Laboratory Analysis}

Feed intake (as-fed basis) for individual cows was recorded daily by the RIC feeding gates and values were used to calculate absolute DMI for the last $5 \mathrm{~d}$ of each period. The DMI for the covariate period was calculated using all $12 \mathrm{~d}$ of observations. Corn silage, alfalfa silage, and concentrate mixes were sampled weekly. Corn starch and oils were sampled during the last week of each period. Forage and concentrate samples were dried at $55^{\circ} \mathrm{C}$ for $48 \mathrm{~h}$ in a forced-air oven. Dried feed samples were then ground to pass through a $1-\mathrm{mm}$ screen (Wiley mill; Arthur H. Thomas Co., Philadelphia, PA), composited for the whole trial, and analyzed for DM, ash, NDF, ADF, CP, ether extract, starch, mineral content, and FA profile. The absolute DM of the feed samples was measured by drying in a $105^{\circ} \mathrm{C}$ oven for 3 h (method 2.1.4; National Forage Testing Association, 
1993). Ash was measured by oven combustion at $600^{\circ} \mathrm{C}$ for $2 \mathrm{~h}$ (AOAC International, 2012; method 942.05). Neutral detergent fiber was determined using method 2002.04 (AOAC International, 2012) modified to use sea sand for the filter aid. Acid detergent fiber was analyzed using method 973.18 (AOAC International, 2012). Crude protein was determined by combustion following method 990.03 (AOAC International, 2012). Starch content was analyzed according to the enzymatic-colorimetric method of Knudsen (1997). Mineral content was measured according to method 953.01 (AOAC International, 2012). Feed FA profile was measured according to the one-step methylation using the chloroform procedure of Sukhija and Palmquist (1988). The internal standard was C19:0 and the resulting FAME were analyzed by using a GC (Clarus 680, PerkinElmer Norwalk, CT) equipped with a $100-\mathrm{m}$ column. The total feed FA concentration was calculated from the sum of all FA from C12:0 to C24:1, with C19:0 used as an internal standard. All composition analyses, except for feed FA profile, were conducted at Dairyland Laboratories Inc. (Arcadia, WI). Diet chemical composition was calculated based on analysis of forages, concentrate mixes, starch, and oils and feed proportions used.

All measurements were collected from individual animals. Milk yield was recorded daily, and milk components were sampled for the last $5 \mathrm{~d}$ of each period at 10 consecutive a.m. and p.m. milkings. For the covariate period, milk components were measured on d 4 and 11. Fat, protein, lactose, and MUN concentrations were measured in individual a.m. and p.m. samples by infrared analysis using a Foss MilkoScan FT6000 (AgSource Laboratories, Menomonie, WI). A second set of milk samples was collected from the a.m. and p.m. milkings on d 20 of each period for milk FA characterization, as described by He and Armentano (2011). Briefly, for each cow, milk samples were pooled by volume from
2 milkings and centrifuged at 17,800 $\times g$ for $30 \mathrm{~min}$ at $8^{\circ} \mathrm{C}$. Milk fat was then collected and stored under nitrogen at $-20^{\circ} \mathrm{C}$ pending FA analysis. Lipid extraction and FA methylation were carried out according to Chouinard et al. (1999a). Resulting FAME were analyzed via GC (Clarus 680, PerkinElmer) equipped with a 100-m column, as described by He and Armentano (2011), with the following modification: for quantitation of individual FA proportions, reference factors were obtained from certified FA mixtures (FIM-FAME-6 and FIM-FAME-7 Mixture, Matreya LLC, Pleasant Gap, $\mathrm{PA})$, rather than a certified butter fat standard.

\section{Diet Composition and FA Profile}

Analysis of the CC, LOC, and supplemented FA diets showed similar nutrient compositions except for starch, $\mathrm{FA}, \mathrm{NE}_{\mathrm{L}}$, and ash (Table 1). Each FA supplement was high in the desired FA (Table 2), and inclusion of each supplement in the diet resulted in increased dietary levels of the respective FA (Table 3 ).

\section{Statistical Analysis}

Data were analyzed using the MIXED procedure of SAS (version 9.3, SAS Institute Inc., Cary, NC). Dry matter intake, milk production, and milk composition variables were analyzed using the model

$$
\begin{gathered}
\mathrm{Y}_{\mathrm{ijklmn}}=\mu+\mathrm{Cov}+\operatorname{Par}_{\mathrm{i}}+\operatorname{Per}_{\mathrm{j}}+\mathrm{T}_{\mathrm{k}}+\left(\operatorname{Par}_{\mathrm{i}} \times \mathrm{Per}_{\mathrm{j}}\right) \\
+\left(\operatorname{Par}_{\mathrm{i}} \times \mathrm{T}_{\mathrm{k}}\right)+\operatorname{Pro}_{1}+\left(\operatorname{Pro}_{1} \times \mathrm{T}_{\mathrm{k}}\right)+\mathrm{S}_{\mathrm{m}}\left(\operatorname{Par}_{\mathrm{i}}\right) \\
+\left[\operatorname{Per}_{\mathrm{j}} \times \mathrm{T}_{\mathrm{k}} \times \mathrm{G}_{\mathrm{n}}\left(\mathrm{S}_{\mathrm{m}}\right)\right]+\mathrm{e}_{\mathrm{ijklmn}}
\end{gathered}
$$

where $Y_{i j k l m n}$ is the response variable; $\mu$ is the overall

\begin{tabular}{|c|c|c|c|c|}
\hline \multirow[b]{2}{*}{$\begin{array}{l}\text { FA } \\
(\mathrm{g} / 100 \mathrm{~g} \text { of } \mathrm{DM})\end{array}$} & \multicolumn{4}{|c|}{ FA source } \\
\hline & $\begin{array}{l}\text { Blend of corn } \\
\text { and safflower }{ }^{1} \text { oil }\end{array}$ & $\begin{array}{c}\text { High-oleic } \\
\text { sunflower oil }\end{array}$ & Palm oil & $\begin{array}{l}\text { Ca salts of } \\
\text { palm FA }\end{array}$ \\
\hline C14:0 & 0.09 & 0.06 & 0.92 & 1.09 \\
\hline C16:0 & 8.35 & 3.55 & 39.7 & 41.8 \\
\hline C18:0 & 1.90 & 3.14 & 3.90 & 3.84 \\
\hline $\mathrm{C} 18: 1^{2}$ & 27.3 & 80.2 & 34.3 & 33.3 \\
\hline $\mathrm{C} 18: 2^{3}$ & 58.0 & 5.84 & 8.17 & 7.87 \\
\hline $\mathrm{C} 18: 3^{4}$ & 0.48 & 0.20 & 0.15 & 0.25 \\
\hline Other & 0.93 & 1.71 & 1.10 & 1.00 \\
\hline Total & 94.5 & 94.7 & 88.3 & 89.1 \\
\hline
\end{tabular}
mean; Cov is the fixed effect of the covariate measure-

Table 2. Fatty acid composition of the FA sources supplemented in the experimental treatments 
Table 3. Fatty acid composition of experimental diets

\begin{tabular}{|c|c|c|c|c|c|c|}
\hline \multirow{2}{*}{$\begin{array}{l}\text { FA } \\
(\mathrm{g} / \mathrm{kg} \text { of diet } \mathrm{DM})\end{array}$} & \multicolumn{6}{|c|}{ Treatment $^{1}$} \\
\hline & $\mathrm{CC}$ & LOC & LO & $\mathrm{OO}$ & $\mathrm{PO}$ & PFA \\
\hline C12:0 & 0.56 & 0.40 & 0.40 & 0.40 & 0.43 & 0.39 \\
\hline C14:0 & 0.20 & 0.22 & 0.24 & 0.23 & 0.38 & 0.33 \\
\hline C16:0 & 3.54 & 2.79 & 4.23 & 3.40 & 9.69 & 8.76 \\
\hline C16:1 & 0.22 & 0.20 & 0.21 & 0.21 & 0.22 & 0.27 \\
\hline C18:0 & 0.64 & 0.51 & 0.83 & 1.05 & 1.18 & 1.08 \\
\hline $\mathrm{C} 18: 1^{2}$ & 2.53 & 1.56 & 5.17 & 15.5 & 7.52 & 6.09 \\
\hline $\mathrm{C} 18: 2^{3}$ & 5.46 & 2.87 & 13.0 & 3.88 & 4.28 & 3.27 \\
\hline $\mathrm{C} 18: 3^{4}$ & 1.36 & 1.96 & 2.04 & 1.99 & 1.98 & 1.92 \\
\hline C20:0 & 0.47 & 0.18 & 0.24 & 0.23 & 0.23 & 0.18 \\
\hline Total & 18.5 & 12.2 & 28.0 & 28.7 & 27.6 & 23.6 \\
\hline
\end{tabular}

ment; Par $_{\mathrm{i}}$ is the fixed effect of parity $(\mathrm{i}=1-2)$; Per $_{\mathrm{j}}$ is the fixed effect of period $(\mathrm{j}=1-6) ; \mathrm{T}_{\mathrm{k}}$ is the fixed effect of treatment $(\mathrm{k}=1-6) ; \mathrm{Pro}_{1}$ is the fixed effect of production level $(1=1-2) ; S_{m}$ is the random effect of square $(m=1-5) ; G_{n}$ is the random effect of gate (n $=1-30)$; and $\mathrm{e}_{\mathrm{ijk} k m n}$ is the random residual error. The Per $\times \mathrm{T} \times \mathrm{G}(\mathrm{S})$ interaction was included to recognize gate as the experimental unit for all fixed effects except for Pro and Pro $\times$ T interaction. Denominator degrees of freedom were specified using the Kenward-Rogers option and ranged from 75.8 to 143 when the random effect of Per $\times \mathrm{T} \times \mathrm{G}(\mathrm{S})$ was significant, and was $>200$ when it was not. Data used for production parameters were from the last $5 \mathrm{~d}$ of each period. Cow averages for a period were calculated using the sum of the average a.m. and p.m. milkings. Fatty acid proportions and yields were analyzed using the same model without the covariate adjustment (Cov). Contrasts were included in the program to examine the effects of fat (LOC vs. added fat treatments), FA type (LO vs. OO, PO, and $\mathrm{PFA} ; \mathrm{OO}$ vs. $\mathrm{PO}$ and $\mathrm{PFA}$ ), and saponification (PO vs. PFA). Because the oils added were not a pure source of any one FA, an alternative linear regression analysis was conducted on the milk FA yield data. Only LOC, $\mathrm{LO}, \mathrm{OO}$, and PO data were used in this analysis. Fatty acid concentration in diet LOC was considered as basal and set to 0 for all FA. The regression model used was

$$
\begin{aligned}
& \mathrm{Y}_{\mathrm{ijkl}}=\mu+ \text { Palmitic }+ \text { Oleic }+ \text { Linoleic }+ \text { Par }_{\mathrm{i}}+\text { Per }_{\mathrm{j}} \\
&+\left(\operatorname{Par}_{\mathrm{i}} \times \text { Per }_{\mathrm{j}}\right)+\mathrm{S}_{\mathrm{k}}\left(\operatorname{Par}_{\mathrm{i}}\right)+[\text { Palmitic } \times \text { Oleic } \\
&\left.\quad \times \text { Linoleic } \times \operatorname{Per}_{\mathrm{j}} \times \mathrm{G}_{\mathrm{l}}\left(\mathrm{S}_{\mathrm{k}}\right)\right]+\mathrm{e}_{\mathrm{ijk} \mathrm{k}},
\end{aligned}
$$

where $Y_{\mathrm{ijkl}}$ is the response variable; $\mu$ is the overall mean; Palmitic is the effect associated with additional
C16:0 above basal; Oleic is the effect associated with additional C18:1 above basal; Linoleic is the effect associated with additional C18:2 above basal (all expressed as $\mathrm{g} / 100 \mathrm{~g}$ of diet DM); $\mathrm{Par}_{\mathrm{i}}$ is the fixed effect of parity $(i=1-2)$; Per $_{j}$ is the fixed effect of period $(j$ $=1-6) ; \mathrm{S}_{\mathrm{k}}$ is the random effect of square $(\mathrm{k}=1-5) ; \mathrm{G}_{1}$ is the random effect of gate $(l=1-30)$; and $\mathrm{e}_{\mathrm{ijkl}}$ is the random residual error. For all analyses, significance was declared at $P<0.05$.

\section{RESULTS AND DISCUSSION}

\section{Nutrient Intakes, Milk Production, and Composition}

We detected no treatment by parity or treatment by production level interactions for any production parameters. Dry matter intake was not affected by treatment (mean $=26.9 \mathrm{~kg} / \mathrm{d} ; P=0.69$; Table 4$)$. This is in agreement with results of previous studies where DMI was not affected by supplementation of $1.5 \%$ corn oil (Leonardi et al., 2005), 3.6 or 4\% soybean oil (Dhiman et al., 2000), or $5 \%$ corn oil, palm oil, or high-oleic safflower oil (He and Armentano, 2011). However, in one study, addition of 1.8\% FA of palm oil increased DMI compared with control (Mosley et al., 2007).

Milk yield was lower for LOC than the average of all FA-supplemented diets ( 40.7 vs. $43.9 \mathrm{~kg} / \mathrm{d} ; P=0.01$ ). This suggests that diets formulated to be artificially low in fat content were limited in either fat or energy, resulting in lower milk yield. Despite the difference in milk yield, milk energy yield was not different for any of the contrasts examined. However, treatment did affect milk energy yield $(P=0.02)$ and $\mathrm{CC}$ was numerically highest. In 2 previous studies, it was reported that adding a fat supplement to the low fat control diet resulted in either no difference in milk yield (He et al., 2012) or 
Table 4. Effect of dietary fat supplements differing in FA composition on intake, milk production, and milk composition

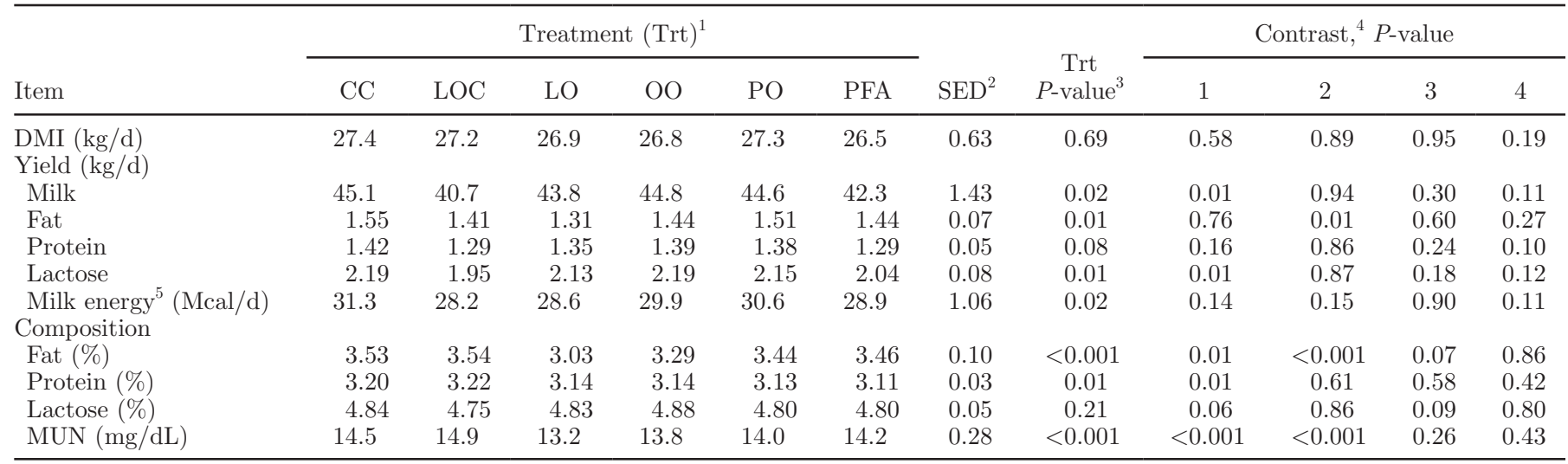

${ }^{1} \mathrm{CC}=$ corn control, $\mathrm{LOC}=$ low-oil control, $\mathrm{LO}=$ corn and high-linoleic safflower oil, $\mathrm{OO}=$ high-oleic sunflower oil, $\mathrm{PO}=$ palm oil, $\mathrm{PFA}=$ calcium salt of palm FA.

${ }^{2} \mathrm{SED}=$ standard error of the difference.

${ }^{3}$ No interaction terms evaluated were significant.

${ }^{4}$ Contrasts: $1=\mathrm{LOC}$ vs. LO, OO, PO, and PFA; $2=\mathrm{LO}$ vs. OO, PO, and PFA; $3=\mathrm{OO}$ vs. PO and PFA; $4=\mathrm{PO}$ vs. PFA.

${ }^{5}$ Milk energy $(\mathrm{Mcal} / \mathrm{d})=(9.29 \times$ fat yield $)+(5.47 \times$ protein yield $/ 0.93)+(3.95 \times$ lactose yield $)$.

increased milk yield (He and Armentano, 2011; He et al., 2012). Mosley et al. (2007) also demonstrated that supplementation of $500,1,000$, or $1,500 \mathrm{~g} / \mathrm{d}$ of FA of palm oil increased milk yield compared with the control; however, increasing supplementation level had no additional effect on milk yield.

Although not tested by a direct statistical contrast, none of the FA-supplemented diets resulted in greater milk energy yields, milk fat yields, or milk fat concentrations than CC. We expected that higher linoleic acid and a larger proportion of forage as corn silage would likely reduce milk fat yield on the $\mathrm{CC}$ diets (Brito and Broderick, 2006). However, in our study substituting feed-grade corn starch and free oils for corn grain starch and oils internal to the feed may have had enough of a negative effect on milk production to offset this. Krause et al. (2003) found no effect on milk fat yield of diets up to $17.9 \%$ refined corn starch (DM), although there was a trend for decreased milk fat percentage as refined corn starch content increased. Additionally, Mohamed et al. (1988) found that when free soybean oil replaced endogenous oil of whole soybeans, milk fat concentration decreased from 3.59 to $2.75 \%$.

The LO diet resulted in lower milk fat yield $(P=$ $0.01)$ and concentration $(P<0.001)$ than the rest of the FA-supplemented diets (Table 4). Dhiman et al. (2000) supplemented 2, 3.6, or 4\% soybean oil (soy oil: 50.1 to $52.0 \% \mathrm{FA}$ as linoleic) to lactating cows and found that milk fat yield and concentration decreased compared with the control, but when soybean oil was supplemented at 0.5 or $1 \%$, no effect on milk fat yield or concentration was observed. The MFD observed in the present study with inclusion of $1.7 \%$ diet DM of a high-linoleic oil (LO) agrees closely with these previous data. The fact that no difference was found between milk fat yield for OO compared with the palm diets $(P=0.60)$, whereas LO was lower than the rest of the FA-supplemented diets supports the argument that linoleic acid is a more potent milk fat depressor than oleic acid (He et al., 2012). Our results are also in agreement with those reported by $\mathrm{He}$ and Armentano (2011), which found that supplementing 5\% of either corn oil or high-linoleic safflower oil decreased milk fat yield compared with a low-fat control, whereas with palm oil supplementation, milk fat yield was similar to the low fat control. In both the previous study (He and Armentano, 2011) and our study, oleic oil supplementation resulted in milk fat yields intermediate between those with linoleic-rich oils and palm-rich supplements.

The LOC diet resulted in a greater milk protein concentration compared with the FA-supplemented diets $(3.22 \%$ vs. $3.13 \% ; P=0.01)$, but protein yield was not increased by this diet. None of the contrasts evaluated differed for milk protein yield $(P>0.05)$. This is in agreement with the published literature in which fat supplementation typically increases milk yield but not milk protein yield, resulting in decreased milk protein concentration (DePeters and Cant, 1992).

Milk urea nitrogen, a measure of protein utilization (Jonker et al., 1998), was higher for LOC than for the FA-supplemented diets (14.9 vs. $13.8 \mathrm{mg} / \mathrm{dL}$; Table 4; $P<0.001)$. An increase in MUN on diets with similar protein intake suggests that less protein was utilized on the LOC diet compared with when FA sources were 
added. The MUN was also lower for LO compared with the other FA-supplemented diets (13.2 vs. $14.0 \mathrm{mg} / \mathrm{dL}$; $P<0.001)$.

\section{Milk FA Yield and Proportion}

We found no interactions between treatment and parity or treatment and production level for any measured FA yields $(P>0.05)$. Contrary to our hypothesis, milk $<$ C16 FA yield was not different for any of the contrasts examined; however, we detected an overall treatment effect $(P=0.05$; Table 5$)$, with diet $\mathrm{CC}$ having the numerically greatest milk $<\mathrm{C} 16$ FA yield. Proportion of $<\mathrm{C} 16 \mathrm{FA}$ in milk fat was also affected by treatment $(P<0.001$; Table 5$)$. An additional 2.96 $\mathrm{g}$ of $<\mathrm{C} 16 \mathrm{FA} / 100 \mathrm{~g}$ of milk FA was produced when LOC was fed compared with the added FA diets $(P$ $>0.001$ ). This difference was not as great as in other studies where total and supplemented dietary FA were higher. For example, He and Armentano (2011) added $5 \%$ oil to a low-oil control and reported a difference of $8.58 \mathrm{~g}$ of $<\mathrm{C} 16 \mathrm{FA} / 100 \mathrm{~g}$ of milk FA between the low-oil control and added oils. In the same experiment, He and Armentano reported decreased milk $<$ C16 FA yield compared with control when 5\% high-linoleic safflower, corn, high-oleic safflower, or palm oils were supplemented. The difference in quantity of fat supplemented (1.7 vs. $5 \%$ of diet DM) and basal level of fat in the control (1.2 vs $1.9 \%$ of diet DM) could explain the lack of similar yield response in the present study.

According to the regression analysis, the greatest change in milk $<$ C16 FA yield was explained by the negative regression coefficient for added linoleic acid $(P=0.02$; Table 6$)$; neither the oleic acid $(P=0.83)$ or palmitic acid $(P=0.69)$ coefficients were different from zero. This result is only in partial agreement with our hypothesis, as well as the study by He et al. (2012), which found relationships between both increasing dietary linoleic and oleic acid and decreasing milk $<$ C16 FA yield, with a more pronounced effect of linoleic acid. The previous trial supplemented greater levels of dietary FA and was designed to specifically examine the effect of dietary oleic and linoleic acids on milk FA yield, while maintaining all other dietary FA constant.

As we hypothesized, regression analysis of milk C16:0 yield revealed a positive coefficient for added dietary palmitic acid $(P<0.001$; Table 6$)$. Milk C16:0 is derived from both dietary $\mathrm{C} 16: 0$ and de novo synthesis (Palmquist, 2006). Therefore, a correlation between dietary intake of palmitic acid and milk yield of C16:0 was to be expected. We also found a negative relationship between milk C16:0 yield and dietary linoleic acid $(P=0.01)$. The presence of this relationship is also exhibited by the fact that milk C16:0 yields were lower for LO compared with all other FA-supplemented diets (369.9 vs. $430.1 \mathrm{~g} / \mathrm{d} ; P=0.01)$ as was the proportion of C16:0 in total milk FA (28.09 vs. $30.12 \mathrm{~g} / 100 \mathrm{~g}$ milk FA; $P=0.01)$. These results were in agreement with our hypothesis. Milk C16:0 yield was also lower for PFA compared with PO $(P=0.05)$. This is likely due to decreased amounts of C16:0 supplied in the PFA diet (8.76 vs. $9.69 \mathrm{~g} / \mathrm{kg}$ of diet $\mathrm{DM})$. The reason for the difference in dietary $\mathrm{C} 16: 0$ between PO and PFA is not clear, because both diets were intended to be similar in C16:0 content.

The OO diet resulted in a lower milk C16:0 yield compared with the palm diets $(P=0.02)$; however, the OO treatment also resulted in greater total milk C18 yield than the palm-based treatments $(P=0.01)$. This difference was also evident in the lower milk C16:0-toC18 ratio for OO than for the palm-based diets $(P=$ 0.02 ; Table 5). These differences are likely due to the composition of the fat sources used in the diets: the palm supplements were over 10 times higher in C16:0 than the high-oleic sunflower oil, and the high-oleic sunflower oil contained nearly twice the C18 FA of the 2 palm supplements (Table 2). Previous work, in which supplemented FA levels were higher than in our study, found that oleic acid can induce MFD but it is less potent than linoleic acid (He et al., 2012). Our data suggest that at the low levels used in this study, linoleic acid can cause MFD, but we were unable to detect depression of either $<\mathrm{C} 16$ or C16:0 FA with oleic acid.

Total milk $\mathrm{C} 18$ yields varied across treatments $(P$ $<0.001)$. The LOC diet resulted in lower total milk C18 yield compared with FA-supplemented diets (378.5 vs. $496.3 \mathrm{~g} / \mathrm{d} ; P<0.001)$. This was likely due to less dietary $\mathrm{C} 18$ being supplied by LOC and thus less preformed $\mathrm{C} 18$ being available for inclusion into milk. This difference was apparent for C18:0 $(P<0.001)$ and total C18:1 $(P<0.001)$, as well as for all of the individual 18-carbon FA measured except for trans-5,cis-11, and cis-13 C18:1 and trans-10,cis-12 CLA (Supplemental Tables S1 and S2; http://dx.doi.org/10.3168/jds.20148328). The total milk $\mathrm{C} 18$ coefficient in the regression analysis was positive for added dietary oleic acid $(P<$ 0.001 ) and was not different from zero for added dietary linoleic acid $(P=0.99$; Table 6$)$. Both treatment oils supplied similar amounts of C18 FA. This suggests that the LO diet slightly impeded incorporation of dietary C18 into the milk.

The overall combined effects of the different dietary FA supplements used in this study on $<\mathrm{C} 16$ and $\mathrm{C} 18$ FA yield are compared with previous results in Figure 1 (present study: solid gray symbols; previous work: open symbols). Our data appear to fit very well with the previously published literature exploring diet-induced MFD at dietary FA levels above 3\%. The basal levels 
Table 5. Effect of dietary fat supplements differing in FA composition on milk FA yield and proportion

\begin{tabular}{|c|c|c|c|c|c|c|c|c|c|c|c|c|}
\hline \multirow[b]{2}{*}{ Item } & \multicolumn{6}{|c|}{ Treatment $(\text { Trt })^{1}$} & \multirow[b]{2}{*}{$\mathrm{SED}^{2}$} & \multirow{2}{*}{$\begin{array}{c}\text { Trt } \\
P \text {-value }\end{array}$} & \multicolumn{4}{|c|}{ Contrast, ${ }^{4} P$-value } \\
\hline & $\mathrm{CC}$ & $\mathrm{LOC}$ & LO & $\mathrm{OO}$ & $\mathrm{PO}$ & PFA & & & 1 & 2 & 3 & 4 \\
\hline \multicolumn{13}{|l|}{ FA yield $(\mathrm{g} / \mathrm{d})$} \\
\hline$<\mathrm{C} 16$ & 473.0 & 416.9 & 381.1 & 417.1 & 432.3 & 395.1 & 29.6 & 0.05 & 0.66 & 0.17 & 0.89 & 0.21 \\
\hline C16:0 & 424.0 & 423.8 & 369.9 & 388.8 & 479.4 & 422.1 & 29.1 & 0.01 & 0.70 & 0.01 & 0.02 & 0.05 \\
\hline C18:0 & 105.2 & 69.6 & 95.6 & 108.5 & 97.9 & 82.0 & 7.5 & $<0.001$ & $<0.001$ & 0.94 & 0.01 & 0.04 \\
\hline Total C18:1 & 336.1 & 260.1 & 330.2 & 382.1 & 347.2 & 314.7 & 20.1 & $<0.001$ & $<0.001$ & 0.28 & 0.01 & 0.10 \\
\hline Total C18 & 505.6 & 378.5 & 482.4 & 545.5 & 502.7 & 454.6 & 29.7 & $<0.001$ & $<0.001$ & 0.45 & 0.01 & 0.10 \\
\hline trans-10 C18:1 & 8.04 & 6.22 & 16.88 & 14.02 & 11.96 & 8.24 & 2.09 & $<0.001$ & $<0.001$ & 0.01 & 0.03 & 0.08 \\
\hline trans-10,cis-12 CLA & 0.11 & 0.11 & 0.19 & 0.14 & 0.10 & 0.10 & 0.03 & 0.01 & 0.24 & 0.01 & 0.09 & 0.82 \\
\hline \multicolumn{13}{|c|}{$\begin{array}{l}\text { FA proportion } \\
(\mathrm{g} \text { of } \mathrm{FA} / 100 \mathrm{~g} \text { of total FA) }\end{array}$} \\
\hline$<\mathrm{C} 16$ & 31.7 & 31.9 & 29.1 & 28.9 & 28.4 & 29.5 & 0.77 & $<0.001$ & $<0.001$ & 0.76 & 0.98 & 0.18 \\
\hline C16:0 & 28.6 & 32.3 & 28.1 & 27.1 & 31.7 & 31.5 & 0.86 & $<0.001$ & $<0.001$ & 0.01 & $<0.001$ & 0.84 \\
\hline Total C18 & 34.7 & 30.0 & 37.3 & 38.5 & 34.3 & 33.7 & 1.29 & $<0.001$ & $<0.001$ & 0.09 & $<0.001$ & 0.63 \\
\hline trans-10 C18:1 & 0.61 & 0.50 & 1.54 & 1.11 & 0.86 & 0.63 & 0.22 & $<0.001$ & 0.01 & $<0.001$ & 0.06 & 0.30 \\
\hline trans-10,cis-12 CLA & 0.0073 & 0.0081 & 0.0148 & 0.0100 & 0.0072 & 0.0069 & 0.0018 & $<0.001$ & 0.26 & $<0.001$ & 0.06 & 0.90 \\
\hline \multicolumn{13}{|l|}{ FA ratio $(\mathrm{g}: \mathrm{g})$} \\
\hline$<\mathrm{C} 16$ to $\mathrm{C} 18$ & 0.96 & 1.14 & 0.81 & 0.78 & 0.87 & 0.91 & 0.05 & $<0.001$ & $<0.001$ & 0.32 & 0.01 & 0.42 \\
\hline $\mathrm{C} 16: 0$ to $\mathrm{C} 18$ & 0.87 & 1.16 & 0.78 & 0.73 & 0.97 & 0.97 & 0.06 & $<0.001$ & $<0.001$ & 0.03 & $<0.001$ & 0.93 \\
\hline
\end{tabular}

${ }^{1} \mathrm{CC}=$ corn control, LOC $=$ low-oil control, $\mathrm{LO}=$ corn and high-linoleic safflower oil, $\mathrm{OO}=$ high-oleic sunflower oil, $\mathrm{PO}=$ palm oil, PFA $=$ calcium salt of palm FA

${ }^{2} \mathrm{SED}=$ standard error of the difference.

${ }^{3}$ No interaction terms evaluated were significant.

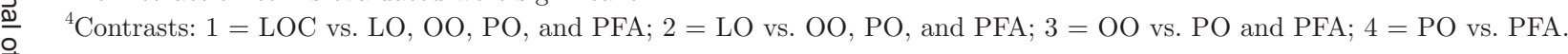




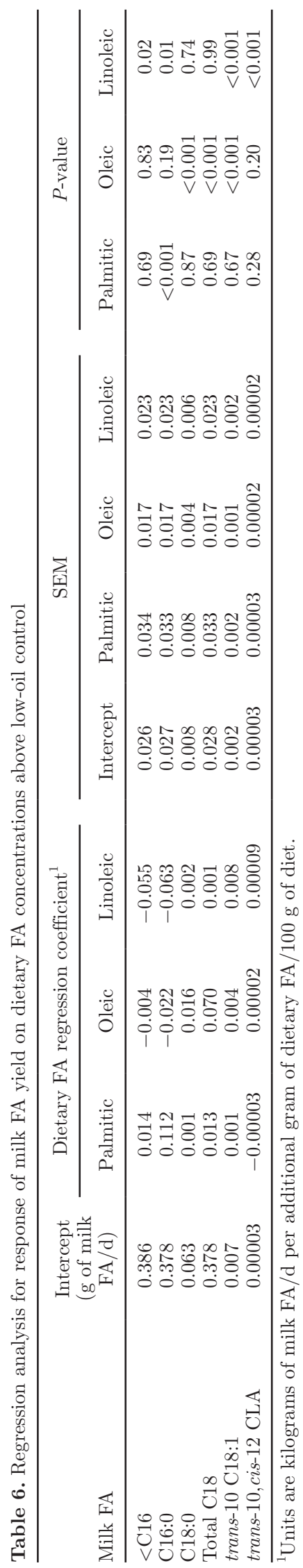

of dietary FA as well as levels of FA supplementation in the current study were lower than any other reported. This means that the decreases in milk $<\mathrm{C} 16$ yield for $\mathrm{OO}, \mathrm{PO}$, and PFA are all well within the lowest quarter of observed values, whereas that for LO is greater, but still less than half the value of the highest reported decreases. In contrast, increases in milk $\mathrm{C} 18$ yield over control for this study ranged between 50 and $150 \mathrm{~g} / \mathrm{d}$, covering most of the range of previously observed differences.

Trans-10,cis-12 CLA causes MFD when infused (Baumgard et al., 2000), and elevated milk trans10,cis-12 CLA corresponds with the MFD seen with increased dietary linoleic acid (He et al., 2012). In the current study, the LO diet resulted in a greater trans10,cis-12 CLA yield in milk than all other diets $(P=$ 0.01 ) and had nearly twice the levels found with LOC (Table 5). Trans-10, cis-12 CLA is a bioactive product of alternative linoleic acid biohydrogenation (Bauman and Griinari, 2003; AbuGhazaleh et al., 2005). Therefore, although milk trans-10,cis-12 CLA yields did not differ between the other contrasts $(P<0.05)$, yields varied as expected in relation to the linoleic acid content of the supplemented oil. The LO diet resulted in the highest trans-10, cis-12 CLA yields, PO and PFA the lowest, and $\mathrm{OO}$ yields were intermediate. This was also apparent in the regression analysis of trans-10,cis-12 CLA yield in milk, which was different from zero only for the positive effect of added dietary linoleic acid $(P<$ $0.001)$.

Trans-10 C18:1 in milk is associated with MFD, although the question of whether it actively causes MFD remains unresolved. Lock et al. (2007) abomasally infused $42.6 \mathrm{~g} / \mathrm{d}$ of trans-10 C18:1. They observed no change in milk fat yield, although the infused trans-10 C18:1 fat was incorporated into milk fat. In contrast, Shingfield et al. (2009) abomasally infused $92.1 \mathrm{~g} / \mathrm{d}$ of trans-10 C18:1 as part of a mixture of trans C18:1 isomers and observed a $19.5 \%$ decrease in milk fat yield. Shingfield et al. (2009) speculate that levels of trans-10 C18:1 flowing into the abomasum during MFD may be several fold greater than those infused in the study by Lock et al. (2007). In our study, milk trans-10 C18:1 yield was lower for LOC compared with all FA-supplemented diets $(P=0.01)$ and was higher for the LO diet compared with the other FA-supplemented diets $(P<$ 0.001). The OO diet also resulted in higher trans-10 C18:1 in milk than PO and PFA $(P=0.03)$. Trans-10 $\mathrm{C} 18: 1$ is an alternative biohydrogenation product of both oleic and linoleic acids (Bauman and Griinari, 2003; AbuGhazaleh et al., 2005) and was thus expected to be higher on the diets high in those oils. Regression analysis of milk trans-10 C18:1 yield revealed positive coefficients for both dietary oleic acid $(P<0.001)$ and 
linoleic acid $(P<0.001$; Table 6$)$. The magnitude of increased milk trans-10 C18:1 associated with added linoleic acid was twice that for oleic acid.

It is unclear if the results found here would be the same if alterations were made to FA present endogenously in feeds rather than in added oils. The reduced ruminal exposure provided simply by being part of a feed particle may reduce conversion of feed FA to bioactive FA in the rumen. Future studies wherein similar feeds with differing endogenous FA profiles are fed would prove useful in determining these effects and thus the usefulness of altering feed FA profiles.

\section{CONCLUSIONS}

When basal dietary fat was low, adding any fat source had positive effects on milk yield, but the effects on milk fat yield depended on the FA composition of the free oil added. Adding linoleic acid in free oil form appears to reduce milk fat yields because milk yield of FA $<18$ carbons were decreased more than any offsetting increase in milk $\mathrm{C} 18$ yield. Adding palm oil, containing both $\mathrm{C} 16: 0$ and $\mathrm{C} 18: 1$, increased milk $\mathrm{C} 16: 0$ yield without impairing short-chain milk FA yield. Although we detected no differences in milk fat yield between added dietary C18:1 and C16:0, the ratio of C16:0 to C18 in milk was different and reflected differences in the oil composition. We created an artificially low fat basal diet to which we could add FA so that the estimated effects of dietary FA in the supplemented diets were more consistent with the concentrations of FA seen in diets not supplemented with FA. Even at these low levels of dietary FA, the FA present had unique effects on milk FA yield, with linoleic being negative, palmitic positive, and oleic intermediate. This suggest that suboptimal dietary FA composition can cause MFD even at low levels of dietary fat and that by shifting to more favorable dietary FA profiles MFD may be decreased.

\section{ACKNOWLEDGMENTS}

This research was partly funded by the United States Department of Agriculture (Washington, DC), under Hatch number WIS1636 and by the Wisconsin Corn Promotion Board (Palmyra, WI). Any opinions, findings, conclusions, or recommendations expressed in this publication are those of the author(s) and do not necessarily reflect the view of the United States Department of Agriculture or the Wisconsin Corn Promotion Board.

\section{REFERENCES}

Abdelqader, M. M., A. R. Hippen, K. F. Kalscheur, D. J. Schingoethe, and A. D. Garcia. 2009. Isolipidic additions of fat from corn germ, corn distillers grains, or corn oil in dairy cow diets. J. Dairy Sci. 92:5523-5533. http://dx.doi.org/10.3168/jds.2008-1867.

AbuGhazaleh, A. A., M. B. Riley, E. E. Thies, and T. C. Jenkins. 2005. Dilution rate and $\mathrm{pH}$ effects on the conversion of oleic acid to trans $\mathrm{C} 18: 1$ positional isomers in continuous culture. J. Dairy Sci. $88: 4334-4341$.

AlZahal, O., N. E. Odongo, T. Mutsvangwa, M. M. Or-Rashid, T. F. Duffield, R. Bagg, P. Dick, G. Vessie, and B. W. McBride. 2008. Effects of monensin and dietary soybean oil on milk fat percentage and milk fatty acid profile in lactating dairy cows. J. Dairy Sci. 91:1166-1174. http://dx.doi.org/10.3168/jds.2007-0232.

AOAC International. 2012. Official Methods of Analysis. 17th ed. AOAC International, Gaithersburg, MD.

Bauman, D. E., and C. L. Davis. 1974. Biosynthesis of milk fat. Lactation: A Comprehensive Treatise. 2. Academic Press, New York, NY

Bauman, D. E., and J. M. Griinari. 2003. Nutritional regulation of milk fat synthesis. Annu. Rev. Nutr. 23:203-227. http://dx.doi. org/10.1146/annurev.nutr.23.011702.073408.

Baumgard, L. H., B. A. Corl, D. A. Dwyer, A. Saebø, and D. E. Bauman. 2000. Identification of the conjugated linoleic acid isomer that inhibits milk fat synthesis. Am. J. Physiol. Regul. Integr. Comp. Physiol. 278:R179-184.

Baumgard, L. H., J. K. Sangster, and D. E. Bauman. 2001. Milk fat synthesis in dairy cows is progressively reduced by increasing supplemental amounts of trans-10, cis-12 conjugated linoleic acid (CLA). J. Nutr. 131:1764-1769.

Bell, J. A., J. M. Griinari, and J. J. Kennelly. 2006. Effect of safflower oil, flaxseed oil, monensin, and vitamin $\mathrm{E}$ on concentration of conjugated linoleic acid in bovine milk fat. J. Dairy Sci. 89:733-748.

Brito, A. F., and G. A. Broderick. 2006. Effect of varying dietary ratios of alfalfa silage to corn silage on production and nitrogen utilization in lactating dairy cows. J. Dairy Sci. 89:3924-3938. http://dx.doi.org/10.3168/jds.S0022-0302(06)72435-3.

Bu, D. P., J. Q. Wang, T. R. Dhiman, and S. J. Liu. 2007. Effectiveness of oils rich in linoleic and linolenic acids to enhance conjugated linoleic acid in milk from dairy cows. J. Dairy Sci. 90:998-1007. http://dx.doi.org/10.3168/jds.S0022-0302(07)71585-0.

Chilliard, Y., C. Martin, J. Rouel, and M. Doreau. 2009. Milk fatty acids in dairy cows fed whole crude linseed, extruded linseed, or linseed oil, and their relationship with methane output. J. Dairy Sci. 92:5199-5211. http://dx.doi.org/10.3168/jds.2009-2375.

Chouinard, P. Y., L. Corneau, D. M. Barbano, L. E. Metzger, and D. E. Bauman. 1999a. Conjugated linoleic acids alter milk fatty acid composition and inhibit milk fat secretion in dairy cows. J. Nutr. 129:1579-1584.

Chouinard, P. Y., L. Corneau, A. Sæbø, and D. E. Bauman. 1999b. Milk yield and composition during abomasal infusion of conjugated linoleic acids in dairy cows. J. Dairy Sci. 82:2737-2745. http://dx.doi.org/10.3168/jds.S0022-0302(99)75530-X.

DePeters, E. J., and J. P. Cant. 1992. Nutritional factors influencing the nitrogen content of milk: A review. J. Dairy Sci. 75:20432070. http://dx.doi.org/10.3168/jds.S0022-0302(92)77964-8.

DePeters, E. J., J. B. German, S. J. Taylor, S. T. Essex, and H. PerezMonti. 2001. Fatty acid and triglyceride composition of milk fat from lactating Holstein cows in response to supplemental canola oil. J. Dairy Sci. 84:929-936.

Dhiman, T. R., L. D. Satter, M. W. Pariza, M. P. Galli, K. Albright, and M. X. Tolosa. 2000. Conjugated linoleic acid (CLA) content of milk from cows offered diets rich in linoleic and linolenic acid. J. Dairy Sci. 83:1016-1027. http://dx.doi.org/10.3168/jds.S00220302(00)74966-6.

Elliott, J. P. P., J. K. K. Drackley, and D. J. J. Weigel. 1996. Digestibility and effects of hydrogenated palm fatty acid distillate in lactating dairy cows. J. Dairy Sci. 79:1031-1039. http://dx.doi. org/10.3168/jds.S0022-0302(96)76456-1.

Fearon, A. M., C. S. Mayne, J. A. M. Beattie, and D. W. Bruce. 2004. Effect of level of oil inclusion in the diet of dairy cows at pasture on animal performance and milk composition and properties. J. Sci. Food Agric. 84:497-504. http://dx.doi.org/10.1002/jsfa.1714. 
Griinari, J. M., D. A. Dwyer, M. A. McGuire, D. E. Bauman, D. L. Palmquist, and K. V. V. Nurmela. 1998. Trans-octadecenoic acids and milk fat depression in lactating dairy cows. J. Dairy Sci. 81:1251-1261.

Grummer, R. R. 1991. Effect of feed on the composition of milk fat. J. Dairy Sci. 74:3244-3257.

Harfoot, C. G., and G. P. Hazlewood. 1997. Lipid metabolism in the rumen. Pages 382-426 in The Rumen Microbial Ecosystem. P. N. Hobson and C. S. Stewart, ed. Chapman and Hall, London, UK.

He, M., and L. E. Armentano. 2011. Effect of fatty acid profile in vegetable oils and antioxidant supplementation on dairy cattle performance and milk fat depression. J. Dairy Sci. 94:2481-2491. http://dx.doi.org/10.3168/jds.2010-3755.

He, M., K. L. Perfield, H. B. Green, and L. E. Armentano. 2012. Effect of dietary fat blend enriched in oleic or linoleic acid and monensin supplementation on dairy cattle performance, milk fatty acid profiles, and milk fat depression. J. Dairy Sci. 95:1447-1461. http:// dx.doi.org/10.3168/jds.2011-4635.

Huang, Y., J. P. Schoonmaker, B. J. Bradford, and D. C. Beitz. 2008. Response of milk fatty acid composition to dietary supplementation of soy oil, conjugated linoleic acid, or both. J. Dairy Sci. 91:260-270. http://dx.doi.org/10.3168/jds.2007-0344.

Jenkins, T. C. 1998. Fatty acid composition of milk from Holstein cows fed oleamide or canola oil. J. Dairy Sci. 81:794-800.

Jonker, J. S., R. A. Kohn, and R. A. Erdman. 1998. Using milk urea nitrogen to predict nitrogen excretion and utilization efficiency in lactating dairy cows. J. Dairy Sci. 81:2681-2692.

Kalscheur, K. F., B. B. Teter, L. S. Piperova, and R. A. Erdman. 1997. Effect of fat source on duodenal flow of trans-C18:1 fatty acids and milk fat production in dairy cows. J. Dairy Sci. 80:2115-2126.

Knudsen, K. E. B. 1997. Carbohydrate and lignin contents of plant materials used in animal feeding. Anim. Feed Sci. Technol. 67:319-338. http://dx.doi.org/10.1016/S0377-8401(97)00009-6.

Krause, K. M., D. K. Combs, and K. A. Beauchemin. 2003. Effects of increasing levels of refined cornstarch in the diet of lactating dairy cows on performance and ruminal pH. J. Dairy Sci. 86:1341-1353. http://dx.doi.org/10.3168/jds.S0022-0302(03)73719-9.

Leonardi, C., S. Bertics, and L. E. Armentano. 2005. Effect of increasing oil from distillers grains or corn oil on lactation performance. J. Dairy Sci. 88:2820-2827.

Leonardi, C., S. Bertics, and L. E. Armentano. 2012. Erratum to "Effect of increasing oil from distillers grains or corn oil on lactation performance" (J. Dairy Sci. 88:2820-2827). J. Dairy Sci. 95:6830. http://dx.doi.org/10.3168/jds.2012-95-11-6830.

Lock, A. L., C. L. Preseault, J. E. Rico, K. E. DeLand, and M. S. Allen. 2013. Feeding a C16:0-enriched fat supplement increased the yield of milk fat and improved conversion of feed to milk. J. Dairy Sci. 96:6650-6659. http://dx.doi.org/10.3168/jds.2013-6892.

Lock, A. L., C. Tyburczy, D. A. Dwyer, K. J. Harvatine, F. Destaillats, Z. Mouloungui, L. Candy, and D. E. Bauman. 2007. Trans-10 octadecenoic acid does not reduce milk fat synthesis in dairy cows. J. Nutr. 137:71-76.

Loor, J. J., K. Ueda, A. Ferlay, Y. Chilliard, and M. Doreau. 2004. Biohydrogenation, duodenal flow, and intestinal digestibility of trans fatty acids and conjugated linoleic acids in response to di- etary forage:concentrate ratio and linseed oil in dairy cows. J. Dairy Sci. 87:2472-2485. http://dx.doi.org/10.3168/jds.S00220302(04)73372-X.

Mohamed, O. E., L. D. Satter, R. R. Grummer, and F. R. Ehle. 1988. Influence of dietary cottonseed and soybean on milk production and composition. J. Dairy Sci. 71:2677-2688. http://dx.doi. org/10.3168/jds.S0022-0302(88)79861-6.

Mosley, S. A., E. E. Mosley, B. Hatch, J. I. Szasz, A. Corato, N. Zacharias, D. Howes, and M. A. McGuire. 2007. Effect of varying levels of fatty acids from palm oil on feed intake and milk production in Holstein cows. J. Dairy Sci. 90:987-993. http://dx.doi. org/10.3168/jds.S0022-0302(07)71583-7.

National Forage Testing Association. 1993. Forage analysis procedures. National Forage Testing Association, Omaha, NE.

NRC. 2001. Nutrient Requirements of Dairy Cattle. 7th rev. ed. National Academy Press, Washington, DC.

Palmquist, D. L. 2006. Milk fat: Origin of fatty acids and influence of nutritional factors thereon. Pages 43-92 in Advanced Dairy Chemistry. Vol. 2 Lipids. P. F. Fox and P. L. H. McSweeney, ed. Springer US, New York, NY.

Perfield, J. W., A. L. Lock, J. M. Griinari, A. Sæbø, P. Delmonte, D. A. Dwyer, and D. E. Bauman. 2007. Trans-9, cis-11 conjugated linoleic acid reduces milk fat synthesis in lactating dairy cows. J. Dairy Sci. 90:2211-2218. http://dx.doi.org/10.3168/jds.2006-745.

Peterson, D. G., L. H. Baumgard, and D. E. Bauman. 2002. Milk fat response to low doses of trans-10, cis-12 conjugated linoleic acid (CLA). J. Dairy Sci. 85:1764-1766.

Piantoni, P., A. L. Lock, and M. S. Allen. 2013. Palmitic acid increased yields of milk and milk fat and nutrient digestibility across production level of lactating cows. J. Dairy Sci. 96:7143-7154. http://dx.doi.org/10.3168/jds.2013-6680.

Rego, O. A., S. P. Alves, L. M. S. Antunes, H. J. D. Rosa, C. F. M. Alfaia, J. A. M. Prates, A. R. J. Cabrita, A. J. M. Fonseca, and R. J. B. Bessa. 2009. Rumen biohydrogenation-derived fatty acids in milk fat from grazing dairy cows supplemented with rapeseed, sunflower, or linseed oils. J. Dairy Sci. 92:4530-4540. http:// dx.doi.org/10.3168/jds.2009-2060.

Shingfield, K. J., A. Sæbø, P.-C. Sæbø, V. Toivonen, and J. M. Griinari. 2009. Effect of abomasal infusions of a mixture of octadecenoic acids on milk fat synthesis in lactating cows. J. Dairy Sci. 92:4317-4329. http://dx.doi.org/10.3168/jds.2008-2002.

Sukhija, P. S., and D. L. Palmquist. 1988. Rapid method for determination of total fatty acid content and composition of feedstuffs and feces. J. Agric. Food Chem. 36:1202-1206.

Warntjes, J. L., P. H. Robinson, E. Galo, E. J. DePeters, and D. Howes. 2008. Effects of feeding supplemental palmitic acid (C16:0) on performance and milk fatty acid profile of lactating dairy cows under summer heat. Anim. Feed Sci. Technol. 140:241-257. http:// dx.doi.org/10.1016/j.anifeedsci.2007.03.004.

Ye, J. A., C. Wang, H. F. Wang, H. W. Ye, B. X. Wang, H. Y. Liu, Y. M. Wang, Z. Q. Yang, and J. X. Liu. 2009. Milk production and fatty acid profile of dairy cows supplemented with flaxseed oil, soybean oil, or extruded soybeans. Acta Agric. Scand. A Anim. Sci. 59:121-129. http://dx.doi.org/10.1080/09064700903082252. 